\title{
EFL Writing Students' Responses towards Teacher Feedback to Enhance Their Writing Quality
}

\author{
Listyani \\ UKSW, Indonesia
}

\begin{abstract}
This study deals with seventy-six students' feelings and perceptions on the teacher feedback that they received from their writing classes. Teacher feedback is sometimes seen as something unwanted, sickening, and even frustrating. Some students do not like getting feedback from their teachers as they think that the feedback corners them, pinpointing their weaknesses and errors. This makes them full of stress and have greater anxiety. Those aspects may be the negative sides of feedback that some students perceive. As a matter of fact, if learners are willing to look deeper into the benefits of feedback that teachers give, especially in writing, they will not feel the negative sides of feedback. Instead, they will crave and wait for it. The purpose of this study is to reveal the perceptions of 76 EFL learners' reactions towards teacher feedback that they received in their writing classes. The results of the study hopefully can inspire writing lecturers to give supportive corrective feedback, so that EFL learners' writing can be improved.
\end{abstract}

Index Terms-EFL, writing, feedback, writing quality

\section{INTRODUCTION}

"Learners need endless feedback more than they need endless teaching." It is a very wise statement from Grant Wiggins (in Cunynghame, 2020), who describes the importance of teacher feedback. Teacher feedback is an important factor that can help students improve the quality of their writing, both in terms of content and language quality. Students in many ways still depend on their teachers' help, either in the form of consultation as a form of direct, spoken feedback or written feedback. In terms of both content and language, many students still rely on their teachers to help them produce a good piece of writing. Panhoon and Wongwanich (2014) even claim that feedback is the most powerful influence on learning. Rachael (2015) suggested that it may be better for teachers to provide feedback on students' grammar and content, while peer students can assist in the organization and academic style.

According to Wiggins (2012), basically, feedback is information about how students are doing in their efforts to reach a goal. An example of this is when a tennis player hits a tennis ball with the goal of keeping it within the court boundaries, and the tennis player will see where it lands, is it in or out of bounds. Also, when someone tells a joke with the goal of making people laugh, the person will observe other people's reactions - whether they laugh loudly or barely snuffle. The same case happens to teachers. When a teacher teaches a lesson with the goal of engaging the students, he/she can see that some students have their eyes focused on the teacher while others are nodding off. Teacher feedback has long been discussed and has also caused some controversies in its effectiveness, importance, as well as functions.

Considering the importance of teacher feedback for tertiary students, especially in the field of writing, this study was thus conducted. There is one central question addressed in this study: How do second language writing students respond to teacher feedback? Students' responses, in this case, constitute their opinions, perspectives, as well as feelings that they had upon receiving teacher feedback on their essays.

The research was done on four classes of writing, that is, Research Proposal Writing, Academic Writing, Writing for the Media, and Creative Writing, in an English Language Education Study Program, in a private university in Central Java, Indonesia. The writing classes were selected based on the consideration that Creative Writing is the first writing class offered to first-year students, while the other two writing classes, Writing for the Media and Academic Writing, are the two highest writing classes before students go to Research Proposal Writing.

The data collection on Research Proposal Writing was conducted in Semester II of the 2018/2019 academic year, involving fifteen (15) students. Then the research on Academic Writing was done on twenty (20) 2017 class year students in Semester III of the 2018-2019 academic year. Data from Writing for the Media was gathered from nineteen (19) 2018 class year students in Semester I of the 2019-2020 academic year. The last data from twenty-two (22) Creative Writing students were also derived from Semester I of the 2019/2020 academic year. Altogether, there were seventy-six (76) student participants in this study. These students were taught by the researchers, and all the students in those classes agreed to become the respondents of this research. The sampling technique was thus random sampling.

This study aimed to investigate students' perceptions of the importance of teacher feedback on their writing, and their feelings towards it. The participants in this study were randomly given initials as Student 1 to Student 76 . The results showed that there were three kinds of second language writing students' responses toward teacher feedback. They had 
positive responses, negative reactions, and mixed opinions.

\section{A. The Definition and Purpose of Feedback}

That many writing students are still very dependent on their teachers' help, including teachers' feedback is an undeniable fact. Students of English as a foreign language still need much help from their writing teachers. One form of teachers' help in second language writing is feedback given to improve students' writing quality, both in language and content. One may wonder what is actually meant by feedback. Regarding the definition of feedback, Zaman and Asad (2012) stated that feedback is a crucial part of writing development. One of the other purposes of giving feedback on learners' writing is because teachers want to give influence on the students' language use in the future and give comments on its past time use (Harmer, 2007, in Zaman \& Asad, 2012).

Feedback can either be supportive or unsupportive. Ellis (2009) stated that supportive feedback affirms that a learner's response to activity is correct. Corrective feedback is actually a kind of unsupportive feedback. This remains debatable among researchers and teachers. Supportive feedback should be motivating and many second language (L2) learners give massive significance to it. On the other hand, it is argued that unsupportive feedback can be disheartening and this can affect learners' attitudes towards feedback; they may act adversely (in Zaman \& Asad, 2012). Zaman and Asad (2012) further asserted that too many and too frequent corrections or unsupportive feedbacks have a demotivating effect on the learners. Lee (2008) claimed that L2 students in general put a high priority on the accuracy of their writing. That is why these learners are eager to have their errors indicated by the teacher.

In practice, according to Park (2014), feedback tends to be infrequent, not well coordinated, unclear, and no actions can be taken on it. Feedback providers, principals, coaches, and peers often lack professional development. They often lack skills, which new teachers need in order to involve themselves in feedback conversations, which are instructive and productive. Because of these problems, some organizational and structural issues at school and district levels may find confusion about the purpose of feedback. Agbayahoun's (2016) research findings also showed that teachers expected that feedback would be a tool to promote students' accuracy in writing, while students hoped that they also got feedback in terms of content.

Hattie and Timperley (2007) also emphasized the importance of feedback. They asserted that feedback is one of the most dominant influences on students' learning and achievements. The impact can be either positive or negative. The power of feedback is frequently mentioned in articles about learning and teaching. Smart (2003) argued that students will decide what works and what does not work based on the feedback that they receive.

Hyland and Hyland's (2006, in Lee, 2008) study suggested that students possibly find teacher feedback useful under two conditions. First, when it involves the student writer, and secondly when it is contextualized. Contextualized means that individual student needs are taken into consideration. Students are more likely to perceive feedback as effective when it is used to build good relationships with students, and it is targeted to their personalities as well as needs. Hence, student reactions seem to be influenced by who the teacher is and how s/he interacts with students during the feedback process.

In dealing with feedback, Tomczyk (2013) asserted that it is essential to distinguish between errors and mistakes. Corder (1967) and Selinker (1972), as cited in Tomczyk (2013), claimed that an error is an unusual form, which results from a lack of knowledge of a particular form, and this reflects a learner's current stage of their interlanguage development. It can be said as a learner's attempt to try something out, even though he/she does not have adequate knowledge yet to produce a given form or item in the correct way.

Corder (1967, in Tomczyk, 2013) added that a mistake refers to a learner's inaccuracy and performance problems, which are temporary in nature. This happens when a student is familiar with a rule, but an incorrect form appears. This can be caused by inattention, fatigue, or the result of a change from one's original plan or intention during the speaking. Truscott (1999) claimed that there is no proof that corrective feedback is helpful. However, teachers treat feedback as something that is always necessary for the language classroom. On the other hand, Lyster, Lightbrown, and Spada (1999, in Tomczyk, 2013), disagreed with Truscott's paper. They claimed that correcting students' deviant forms seldom hurts their self-esteem. In fact, most learners expect to receive corrective feedback. Deci and Ryan (1985, in Maherzi, 2012, p. 774) maintained that supportive feedback would allow the individual to be competent. In contrast, the feeling of "incompetence or amotivation" may result from constant unsupportive feedback.

\section{B. Emotions and Feedback}

Dowden, Pittaway, Yost, and McCarthy (2013) conducted research on student perceptions of feedback, while Young (2000) studied the relationship between self-esteem and feedback (in Taggart \& Laughlin, 2017). The first mentioned study dealt with the collection of survey and focus group data. It found that there was increased attention given to the relationships between emotions and feedback. The second study revealed that predictably, self-esteem seems to significantly affect student responses to feedback. Students with higher self-esteem had more positive attitudes towards receiving feedback and often perceived unsupportive comments as positive, while students with lower self-esteem did not.

Another researcher, Lee (2008, p. 145), claimed that without understanding students' feelings and responses to teacher feedback, teachers may run the risk of continually using counter-productive strategies. When teachers give feedback on student writing, it is essential that student responses to the feedback be returned back to teachers as an 
empirical approach. This is important to help teachers develop reflective and effective feedback practices. Still, according to Lee (2008), previous research on student views of feedback has constantly shown that students treasured and appreciated teacher feedback. They also gave much greater attention to it than other types of feedback like audio feedback, peer evaluation, or self-evaluation.

\section{Feedback in Red Ink}

Raihany (2014) mentioned that many teachers often give feedback on the students' work, especially writing tasks, in the form of returned papers covered with red ink. This actually can result in students' disheartenment and lack of selfconfidence. Even worse, teachers often mark and correct the surface errors in students' compositions, write brief comments, or sometimes no comments at all. They often use only underlining or circular signs and finally provide a grade as a result, and their students' writing results do not improve much. Pitifully, many teachers are not aware of this.

Raihany (2014) further stated that feedback plays an important role in motivating further learning because it informs learners about the results of their learning or their needs for improvement. Feedback is also essential for improving not only learning, but also and teaching. It enables teachers to find out to what point they have been successful in their teaching and what they need to do to make their teaching more effective. Feedback also influences learning in that it provides an opportunity for learners, mainly EFL learners, to know what they need to do in order to improve.

Receiving a corrected piece of work full of the teacher's judgmental comments in bright red ink can indeed be frustrating. Nevertheless, a teacher's written comments on a student's paper can be encouraging and motivating. Being motivated, the student may then produce a much better piece of writing than the corrected one. This is what is called corrective feedback from the teacher. Hyland (2002) affirmed that feedback, either from a tutor or from peer students, is a central element of a writing course.

Balu, Alterman, Haider, and Quinn (2018, p. 11) discussed an institution that really gives special attention to feedback. A school in New York City conducts a program called New Visions. In this program, teachers have an opportunity to give their students more pointed comments and suggest the steps for revision. All of this is integrated into online assignments. In the second year, teachers' comments will focus on sentence-level revisions, which are easier for students than revisions related to an entire assignment. It is an example of integrating technology with student writing and teacher feedback.

\section{Previous Studies}

Some studies have been done in the area of teacher feedback.

In 2007, Hattie and Timperley reviewed 196 studies on feedback and concluded that "effective feedback can almost double the average student growth over a school year" (in the Australian Institute for Teaching and School Leadership (AITSL), 2019, p. 4). Black and Wiliam (2010, as cited in AITSL, 2019), asserted that many studies also showed that an improved formative assessment called feedback, helps lower-achieving students to perform better. Teacher feedback also can raise the overall standards of students' attainment while reducing the gap between higher- and lower-achieving students at the same time. According to AITSL, effective feedback practices will provide a bridge between two important aspects, that is, assessments and learning (2019).

Tomczyk (2013) also conducted a study with a purpose to compare teachers' and students' perceptions of oral errors and their corrective feedback, which is an inseparable part of language acquisition. As many as forty-three (43) secondary school teachers and 250 English as a Foreign L Language (EFL) learners became the participants of the study. They filled out questionnaires and they were observed in real-life situations in the language classroom. The findings revealed that corrective feedback is an important part of language learning. It was even expected by most students. Besides that, the majority of the teachers and learners stated that grammatical and pronunciation errors seemed to be the most important as far as error correction is concerned. The findings also showed that "it is the teacher who is regarded as a competent, non-erring and ultimate authority" (p. 930). Therefore, teachers are supposed to provide corrective feedback whenever deviant forms occur.

Another researcher, Elsaghayer (2014), conducted a study on one hundred ten (110) EFL learners found that the respondents reacted emotionally towards corrective teacher feedback. It sounds contradictory to Lyster, Lightbrown, and Spada's (1999) opinion (in Tomczyk, 2013, p. 2) that correcting students' deviant forms seldom hurts their selfesteem, and that most learners expect to receive corrective feedback.

Suarez, Cerezo, Rosario, and Valle's (2015) study dealt with a survey in Bangladesh, which explored EFL university teachers' and learners' perceptions of the issue of feedback. The results of the survey indicated that both the teachers and learners had very positive attitudes towards corrective feedback. Besides that, they also paid great attention to feedback on the word form.

Taggart and Laughlin (2017) surveyed 343 students nationwide who took a writing-intensive course. They were asked to learn about the moments when they were not able to take teacher feedback and use it to revise. They were also asked to recall the times when they used feedback against their own judgment. It was found that students' expressions of the negative moments often reflected a hierarchy. They felt disrespected and confused. They had common desires, which were for more time and space, respect, and clearly worded, consistent instructions. This is in line with Brookheart's (2008) opinion. She proposed that good teacher written feedback has clarity, with specificity not too broad nor too narrow, and tone in dealing with word choice and language style. 
In 2019, Arndt also conducted a study on corrective feedback. Ten participants from his study supported both direct and indirect feedback methods. These learners believed that when they understood why an error was marked, they would be able to incorporate the feedback into their present as well as future writing tasks, thus becoming better writers.

From the elaborations above, it can be clearly seen that there are many things that are interrelated with a teacher's feedback. Teacher feedback can be encouraging, a kind of "approval" which adds students' satisfaction in their successful learning process. This satisfaction is rooted in their intrinsic motivation. The role of the teacher's feedback, which is corrective and encouraging, then, cannot be taken for granted. It should be given a special place in the teacher's mind map. On the other hand, teacher feedback can also be negative, discouraging, and disheartening. What is meant by unsupportive feedback is actually corrective feedback. In this case, it is important for a teacher to use wise words to write one's feedback. This is basically meant to help students perform better and not the other way around.

\section{RESEARCH METHODOLOGY}

Data for this research was taken from participants' questionnaire answers from four different writing classes. The first questionnaires were collected at the end of Semester II in the 2018/2019 academic year (around April 2019), from Research Proposal Writing, involving fifteen (15) students. Next, data collection was also done on twenty (20) 2017 class year students at the end of Semester III in the 2018-2019 academic year (around July 2019) for Academic Writing students. Data from Writing for the Media was gathered from nineteen (19) 2018 class year students at the end of Semester I in the 2019-2020 academic year (around December 2019). The last data was from twenty-two (22) Creative Writing students and was also derived at the end of Semester I in the 2019/2020 academic year (around December 2019). Altogether, there were seventy-six (76) student participants in this study. The researcher taught all these students.

Interviews were also conducted with five (5) students in April 2020 to validate the students' answers, and also to ask for clarification from vague or ambiguous answers. All the data collected, both the journals and interviews, was done in English. In all these writing classes, many kinds of activities were conducted, like small group discussions in the form of peer assessments to examine a peer's introduction, body, and conclusion. For daily writing exercises in dealing with writing skills like paraphrasing, summarizing, writing in-text citations, or writing parts of the essay, like the introduction, body paragraphs, and conclusion, the students submitted hard copies. This made it easier for them to assess each other's work while doing a peer assessment or peer review. For the complete final drafts, however, they were asked to submit them in the form of soft copies through an educational platform.

There were basically three themes drawn from the questionnaire answers, that is, favorable, unfavorable, and mixed opinions towards teacher feedback. The participants in this study were given initials of P1 until P76. In order to be ethical and respect the confidentiality of the participants' data, their real names were not mentioned. Table 1 clarifies the participants in this study.

TABLE 1.

STUDENT PARTICIPANTS

\begin{tabular}{lll}
\multicolumn{1}{c}{ Initials } & \multicolumn{1}{c}{ Classes } & \multicolumn{1}{c}{ Academic Years when the Classes were } \\
& & \multicolumn{1}{c}{ Offered } \\
\hline P1 - P15 (15 students) & Proposal Writing class & Semester II/ 2018-2019 \\
\hline P16 - P35 (20 students) & Academic Writing class & Semester III/ 2018-2019 \\
\hline P36 - P57 (22 students) & Writing for the Media class & Semester I/ 2019-2020 \\
\hline P58 - P76 (19 students) & Creative Writing class & Semester I/ 2019-2020 \\
\hline
\end{tabular}

\section{RESULTS AND ANALYSIS}

In this study, there were two main questions asked in the questionnaires. The first question was: Do you think that teacher feedback is necessary? And the second question was: How do you feel when you get teacher feedback? For the interview, there was only one question asked: Can you please elaborate on your feelings when you get teacher feedback in more detailed statements? Various answers were derived from the questionnaires as well as interview sessions with the students.

From all the participants in this study, it was found that there were 49 student participants $(64.47 \%)$ who had good or positive perceptions towards teacher feedback in their writing classes. Ten students (13.16\%) displayed unfavorable attitudes towards teacher feedback, and the remaining seventeen students $(22.37 \%)$ had mixed perceptions towards teacher feedback. Here is the detailed information on the perceptions.

\section{A. Students with Good Perceptions towards Teacher Feedback}

Out of 76 participants in this study, $49(6.47 \%)$ showed that they had positive or good perceptions of teacher feedback. Most of these students mentioned that teacher feedback was necessary and it helped them a lot in their writing. Twenty-three (23) students claimed that they felt happy and helped by teacher feedback. Some participants' quotations were as follows, "I am happy because when I get handwritten feedback, I can see some details" (Participant 1, Proposal Writing class). A similar statement came from Participant 7, "I feel satisfied with the teacher feedback because it helps 
me do my research in an organized way" (Participant 7, Proposal Writing class).

Besides the 23 students who showed positive attitudes towards teacher feedback, five (5) students talked about having a better understanding of writing. They claimed that the teacher feedback made them understand better. This is one student's statement, "Teacher feedback makes me understand about my paper better and I can make better sentences/ paragraphs after getting feedback from my teacher" (Participant 59, from Creative Writing class). Similar statements were also stated by P4, P51, P60, and P62. Eleven (11) other students admitted that feedback made them know their mistakes. The feedback helped them identify their errors and mistakes and it made it easier for them to revise their work.

Excerpt 1:

Ifeel thankful because through the teacher feedback I can improve my writing and make it better. If I do not get feedback, I do not know where my mistakes are. From this, I can learn from my mistakes. (Participant 49, Writing for the Media class)

Excerpt 2:

Teacher feedback is necessary for me because I can know my writing errors, and I feel happy because it is meaningful for me.

(Participant 50, Writing for the Media class)

Four (4) other students said that they were happy because getting teacher feedback meant that their teacher cared for them. They felt that their teacher showed her willingness to help through feedback. "I feel like my teacher really read my essay and had a willingness to help me" (Participant 28, Academic Writing class). A similar statement was also mentioned by Participant 74. "I feel really happy because I think the teacher really cares about our work and I think that the teacher appreciates our work. Even when there's something wrong, the teacher helps us a lot to fix our work" (Participant 74, Creative Writing class).

Still included in the positive attitude group, the remaining six (6) students gave distinct and different answers. It can be said that they gave unique answers. Participant 46, for example, mentioned that her writing skills have improved because of the teacher feedback on her writing. Participant 55 admitted that the teacher feedback became a kind of reflection for her that she should do better and correct her mistakes in the past. Participant 57 felt that he was motivated to improve his writing so that he could get better scores in the next assignment. Participant 58 mentioned that she felt a personal touch when getting feedback from her teacher. Participant 67 even admitted that she loved seeing her teacher's handwriting in the feedback. The last participant, Participant 72, mentioned that she appreciated and liked her teacher's feedback because it was fun to see the feedback. Excerpts 9 and 10 show some of the statements from the participants: "I like and appreciate my teacher's feedback, and it is fun to see the feedback" (Participant 72, Creative Writing class), and "I feel that my teacher's feedback is friendly, and I feel a personal touch in the feedback" (Participant 58, Creative Writing class).

The fact that the teacher feedback made the participants realize their errors is in line with Sidorova's (2016) study. The indirect written corrective feedback that the English language learners received over the course of the study had a positive effect on their views and written accuracy.

In summary, there were various reasons why the 49 student participants in this study had good or positive perceptions towards teacher feedback. Table 2 shows the overall reasons.

TABLE 2 .

STUdENTS’ Positive RESPONSES TOWARDS TEACHER FEEDBACK

\begin{tabular}{llc}
\hline \multicolumn{1}{c}{ Initials } & \multicolumn{1}{c}{ Reasons for Having Positive Opinions } & Number \\
\hline $\begin{array}{l}1,7,9,10,11,14,19,20,22,24,25,26,27, \\
30,33,34,36,37,38,44,45,71,76\end{array}$ & Teacher feedback helped them & 23 \\
\hline $4,51,59,60,62$ & $\begin{array}{l}\text { Teacher feedback enhanced their } \\
\text { understanding of how to write well }\end{array}$ & 5 \\
\hline $6,12,15,48,49,50,56,64,66,68,69$ & $\begin{array}{l}\text { Teacher feedback made them know their } \\
\text { errors/ mistakes }\end{array}$ & 4 \\
\hline $28,43,61,74$ & $\begin{array}{l}\text { Teacher feedback made them appreciate } \\
\text { their teacher }\end{array}$ \\
\hline $46,55,57,58,67,72$ & Other answers \\
\hline Total number & \\
\hline
\end{tabular}

The problem of teacher feedback has been highlighted by Hyland and Hyland (2006, as cited in Lee, 2008). As previously mentioned above, they claimed that students are more likely to find teacher feedback useful when it involves the student writer and when it is contextualized, meaning that individual student needs are taken into consideration. Students themselves are more likely to perceive feedback as effective when it is used by teachers to build good relationships with students, and it is targeted to their personalities as well as needs. Hence, student reactions seem to be influenced by who the teacher is and how s/he interacts with the students during the feedback process. 


\section{B. Students with Negative Perceptions towards Teacher Feedback}

Out of 76 student participants, there were ten (10) participants who thought of teacher feedback negatively. There were three reasons for not liking teacher feedback. The first reason was that it was difficult to understand the teacher's handwriting. There were five students who stated this: P16, P17, P18, P31, P65, and P70. The second reason was that they found it difficult to understand the symbols used in marking their papers. It was stated by P2 and P54. The last two student participants, P39 and P40, admitted that they were nervous and worried to see their teacher's feedback. It means that teacher feedback was in a way threatening for them. Below are some excerpts of the students who had negative perceptions of their teacher feedback. "I am nervous to get feedback on my paper because it means that I made many mistakes and I should fix them" (Participant 39, Writing for the Media class). Participant 40 also stated a similar thing. "I feel worried about how many mistakes I made in my paper" (Participant 40, Writing for the Media class).

This is in line with what Deci and Ryan (1985, in Maherzi, 2012, p. 774) stated. They maintained that supportive feedback would allow students to be competent. "When there is no external pressure, the feedback would positively affect students' intrinsic motivation to accomplish optimally stimulating, moderately difficult activities". In contrast, feelings of incompetence or loss of motivation might emerge from constant unsupportive feedback.

\section{Students with Mixed Perceptions towards Teacher Feedback}

The rest of the student participants, 17 people, had mixed perceptions towards teacher feedback. They perceived the feedback both positively and negatively. Four of them mentioned that they were happy to get teacher feedback, but somehow felt unconfident, nervous, and afraid to get their teacher's feedback (P8, P41, P52, P63). These quotations show these participants' nervousness: "I felt happy but my heart beats fast every time I get feedback from my teacher. Feedback really helps me 'repair' my mistakes" (Participant 8, Proposal Writing class), and "I feel unconfident because it means that my work is not perfect, just as I had expected. But I also feel happy because I can fix my mistakes" (Participant 41, Writing for the Media class).

\section{DISCUSSION}

The fact that feedback can be either positive or supportive and negative or unsupportive has previously been discussed. Folkman (2006) mentioned that for many people, giving and receiving feedback is seen as something negative more than positive. In reality, most feedback results contain both supportive and unsupportive feedback. Nevertheless, most people focus on the negative side and believe that the key to self-improvement is found in fixing their own weaknesses, which can either be positive or negative. Ellis (2009) stated that supportive feedback shows that a learner's response to activity is correct.

On the other hand, unsupportive feedback signals that the learner's utterance or writing lacks veracity or is linguistically not right. Ellis (2009) also claimed that corrective feedback is actually a kind of unsupportive feedback. Alhosani (2008, in Tsao, Tseng, and Wang, 2018) claimed that the purpose of giving written corrective feedback is basically to help learners improve their writing proficiency. This can be done by minimizing errors and maximizing clarity in their pieces of writing. Up to now, this case remains debatable among researchers and teachers. It can further be interpreted that supportive feedback is motivating and many second-language learners (L2 learners) place great attention to it. On the other hand, unsupportive feedback may make learners demotivated and this finally makes their attitudes adverse towards feedback (as cited in Zaman \& Asad, 2012).

Seven student respondents admitted that they were glad getting teacher feedback. However, they had difficulties understanding their teacher's handwritten feedback. The writing was sometimes unclear and they could not understand what the teacher meant. These student participants were P5, P13, P21, P23, P29, P32, and P35.

All the participants who were interviewed in April 2020 (P1, P2, P6, P18, and P65) stated a similar perception. When they did not understand the teacher's feedback or the symbols in the feedback, they preferred asking the teacher directly to get a clearer understanding of the meaning. Three of them, P2, P18, and P65, also asked their peer students whom they thought were more capable than they were. If their peer students could not give satisfactory answers, they would resort to their lecturer.

The last seven student participants (P3, P35, P42, P47, P53, P73, P75) had their own unique answers. P42 and P47, for example, felt that they needed face-to-face interactions or direct interactions with the teacher to get the teacher's message across. P3 admitted that sometimes he felt encouraged and sometimes discouraged after getting teacher feedback, depending on the teacher. P53 felt that teacher feedback was necessary; however, it made his assignment "dirty" or untidy. P73 thought that he was happy to get teacher feedback because he could know his mistakes. However, he was unhappy to rewrite or revise his work. Similar to P73, P75 felt that revising was not easy for him.

Excerpt 3:

It (teacher feedback) is necessary because it helps us to know our errors. However, I prefer having face-to-face feedback so that I can communicate better with the teacher. (Participant 42, Writing for the Media class)

Excerpt 4: 


\section{I could feel either really encouraged or discouraged depending on the teacher, the color of pen used, and content of the feedback. A red glaring pen will discourage me, but other colors won't. (Participant 3, Proposal Writing class)}

Students' preference of direct feedback is in line with Fithriani's (2017) study. One of the findings of her study mentioned that students preferred a direct rather than an indirect form of feedback. This has also been mentioned previously. Lee (2008) explained that how students respond to feedback might be influenced by the teacher who delivers the feedback. Wihastyanang, Kusumaningrum, Latief, and Cahyono's (2019) experimental study on 55 English Department students, however, found that students who had an online teacher and peer feedback provided through Edmodo did not perform better in writing than those who experienced teacher feedback in the conventional offline method.

Lee (2008) asserted research findings such as students' welcome praise (Gee, 1972) and students like to receive both praise and constructive criticism (Ferris, 1995; Hyland, 1998), which are examples of generalizations that need to be examined further. Who the teacher is and how the comments are given the need to be researched more deeply.

The use of threatening ink in giving feedback has also been discussed. Raihany (2014) mentioned that many teachers often give feedback on the students' work, especially writing work, and return them with glaring red ink. This can result in students' discouragement and a lack of self-confidence. It is often found that teachers mark and correct the surface errors in students' compositions, write brief comments, or sometimes give no comments at all. They often use codes, which are confusing for students without explaining the meaning first, like underlining or circular signs, and finally provide a grade. As a result, their students' writing, sad to say, does not improve much. However, many teachers are not aware of this and still continue to do it.

\section{CONCLUSION AND RECOMMENDATIONS}

From the discussion above, several inferences can be drawn. First, there are some characteristics of teacher feedback. The nature of teacher feedback varies from being negative, positive or constructive, and neutral. Unsupportive feedback can make students demotivated, discouraged, anxious, or even afraid.

Secondly, students' responses toward teacher feedback also vary. A good type of feedback that students are waiting for would be one that is contextualized, meaning that is adjusted with students' conditions as well as needs. This, however, may lead to another question: How can teachers understand students' needs and conditions when giving feedback? This can be another area to be researched. The third point worth considering is that any type of feedback, whether it is written, typed, face-to-face, or online, has its own strengths and weaknesses. Provided that it can cater to students' needs and help solve students' problems, it should not matter.

In a special condition like the one amidst the coronavirus outbreak, almost all things are done online, including classes and consultations. This may trigger another problem when students cannot see their lecturer in person to ask for clarification or elaboration. This also needs to be highlighted. When students receive online feedback, what problems do they face? For students who can have a videoconference with the lecturer, it does not become a problem. What about those who are short of cellular data fund credit or lack a good Internet connection? This may lead to other problems.

Regarding students' responses toward teacher feedback, some students exhibit positive, negative, and mixed attitudes towards teacher feedback. In this study, it was found that 49 student participants $(64.47 \%)$ had good or positive perceptions towards teacher feedback in their writing class. Ten students $(13.16 \%)$ showed unfavorable attitudes towards teacher feedback, and the remaining seventeen students $(22.37 \%)$ had mixed perceptions towards teacher feedback.

To bridge the gap between writing lecturers' and students' expectations in terms of feedback, EFL writing lecturers should consider the three parameters of effective written feedback as mentioned by Brookheart (2008), which are the clarity of the language in the feedback, the tone of the feedback, and how to deal with the word choice and style. Subconsciously, writing lecturers may show their emotions and dissatisfaction through the tone of feedback. This, in turn, may cause learners to be discouraged and lose motivation. In the worst cases, it even may result in lower selfesteem or self-confidence. The other thing is specificity, meaning that the feedback is not too narrow nor too broad which may confuse learners. Besides giving feedback with clear language, the right tone, and good specificity, EFL writing teachers should also creatively use any possible means to suit the learners' needs and concerns (Hamp-Lyons \& Hyland, in Seker \& Dincer, 2014).

This study hopefully yields some pedagogical contributions regarding the area of feedback and hopefully, this study helps shed a light on the area of teacher feedback; that is, second language writing lecturers can have some ideas of what kind of feedback is constructive and contextualized for their students. Future researchers can conduct research with more participants, not only in writing courses but also in other areas like speaking, listening, or grammar classes.

\section{APPENDIX A. QUESTIONNAIRE QUESTIONS}

1. How do you feel when you get your teacher's feedback? Please explain.

2. Is it clear for you?

3. How does your teacher usually give feedback? Written or typed? 
4. Does your teacher ever use red ink to give feedback? How do you feel?

5. Do you feel any personal touch when feedback is given with handwriting?

6. Do you think your teacher is more expressive when using handwritten feedback?

\section{APPENDIX B. INTERVIEW QUESTIONS}

Student 1:

You said in the previous questionnaire that you like to get hand-written feedback in writing because you can see the details in the feedback.

What if you don't get detailed feedback? Or, what if you get feedback that you don't understand. What do you usually do?

Student 2:

You said in the previous questionnaire that you are happy when you get feedback because you can know directly what your mistakes are. What if you get feedback from your teacher in writing, but you don't understand what to do? What are you going to do?

Student 6:

You said in the previous questionnaire that sometimes you are not happy with teacher feedback because you don't understand the symbols/ marks made by your teacher in your writing. In this case, what do you usually do?

Student 18:

In the previous questionnaire, you said that you sometimes did not like getting your teacher's feedback in writing class because you cannot read the teacher's handwriting which is unclear. In this case, what do you do?

Student 65:

In the previous questionnaire, you said that you sometimes did not like getting your teacher's feedback in writing class because you cannot read the teacher's handwriting which is unclear. In this case, what do you do?

\section{REFERENCES}

[1] Agbayahoun, J. P. (2016). Teacher written feedback on student writing: Teachers' and learners' perspectives. Theory and

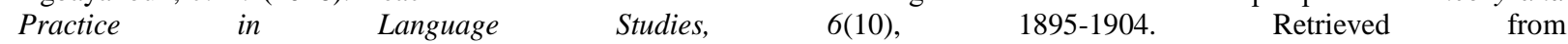
http://www.academypublication.com/issues/tpls/vol06/tpls0610.pdf on October 20, 2019.

[2] Arndt, R. (2019). A qualitative study of corrective feedback. Retrieved from https://repository.stcloudstate.edu/cgi/viewcontent.cgi?article=1028\&context=tesl_etds on July 29, 2020.

[3] Australian Institute for Teaching and School Leadership (AITSL). (2018). Reframing feedback to improve teaching and learning. Retrieved from https://www.aitsl.edu.au/docs/default-source/research-evidence/spotlight/spotlightfeedback.pdf?sfvrsn=cb2eec3c_12 on September 27, 2019.

[4] Balu, R., Alterman, E., Haider, Z., \& Quinn, K. (2018). Student writing, teacher feedback, and working online. Retrieved from https://www.mdrc.org/sites/default/files/DrivetoWrite_2018_Brief.pdf on September 27, 2020.

[5] Brookheart, S. M. (2008). How to give effective feedback to your students. Alexandria: ASCD Publications. Retrieved from http://www.ascd.org/ASCD/pdf/siteASCD/publications/books/How-to-Give-Effective-Feedback-to-Your-Students-2ndEdition-sample-chapters.pdf on May 20, 2020.

[6] Cunynghame, J. (2020). Revision. Retrieved from https://www.pinterest.com/johncunynghame/revision/ on July $29,2020$.

[7] Elsaghayer. M. (2014). Affective damage to oral corrective feedback among students in Libyan secondary schools. IOSR Journal of Research \& Method in Education, 4(6), 74-82. Retrieved from https://pdfs.semanticscholar.org/b9aa/f0adbef1b5135e6ab0fff5eecc8e7a85252a.pdf on October 20, 2020.

[8] Fithriani, R. (2017). Indonesian students' perceptions of written feedback in second language writing. A Dissertation. The University of $\quad$ New $\quad$ Mexico. https://digitalrepository.unm.edu/cgi/viewcontent.cgi?article=1085\&context=educ_llss_etds on July 29, 2020.

[9] Folkman, J. R. (2006). The power of feedback: 35 principles for turning feedback from others to personal and professional change. Hoboken: John Wiley \& Sons, Inc.

[10] Hattie, J., \& Timperley, H. (2007). The power of feedback. Review of Educational Research, 77(1), 81-112. DOI: 10.3102/003465430298487. Retrieved from http://www.columbia.edu/ mvp19/ETF/Feedback.pdf on September 27, 2020.

[11] Hyland, K. (2002). Teaching and researching writing. London: Pearson Education.

[12] Lee, I. (2008). Student reactions to teacher feedback in two Hong Kong secondary classrooms. Journal of Second Language Writing, 17(2008), 144-164. Retrieved from http://www.fed.cuhk.edu.hk/ aflwrite/article/Student\%20reactions\%20to\%20teacher\%20feedback.pdf on October 20, 2020.

[13] Maherzi, S. (2012). Perceptions of classroom climate and motivation to study English in Saudi Arabia: Developing a questionnaire to measure perceptions and motivation. Electronic Journal of Research in Educational Psychology, 9(2), 765798. Retrieved from http://web.a.ebscohost.com/ehost/pdfviewer/pdfviewer?vid=16\&sid=9823cb5c-bd1f-43e9-a3abe1f87bbc2c47\%40sessionmgr4006 on May 24, 2020.

[14] Park, S. (2014). Learning Teaching (LT) Program in Developing an Effective Teacher Feedback System: 90-Day Cycle Report. Retrieved from https://www.carnegiefoundation.org/wp-content/uploads/2013/08/CF_Feedback_90DC_2014.pdf on September 27, 2020.

[15] Panhoon, S., \& Wongwanich, S. (2014). An analysis of teacher feedback for improving teaching quality in primary schools. Procedia - Social and Behavioral Sciences, 116(2014), 4124-4130. Retrieved from https://www.researchgate.net/publication/275543341_An_Analysis_of_Teacher_Feedback_for_Improving_Teaching_Quality_i 
n_Primary_Schools on February 18, 2020.

[16] Rachael, R. (2015). The relative effects of peer and teacher feedback on improvement in EFL students' writing ability. Linguistics and Education, 29, 79-82. Abstract. Retrieved from http://web.b.ebscohost.com/ehost/detail/detail?vid=4\&sid=a3b840a8-f722-4c8c-bb38-d66359d34df0\%40pdc-vsessmgr02\&bdata=JnNpdGU9ZWhvc3QtbGl2ZQ\%3d\%3d\#AN=101930191\&db=a9h on May 24, 2020.

[17] Raihany, A. (2014). The importance of a teacher's written feedback on the students' writing in the teaching learning process. OKARA Journal, $l(9), \quad 91-106 . \quad$ Retrieved from https://www.google.com/url?sa=t\&rct=j\&q=\&esrc=s\&source=web\&cd=1\&ved=2ahUKEwjQtemzqvvoAhVGSX0KHT1JDcA QFjAAegQIAhAB\&url=http\%3A\%2F\%2Fejournal.stainpamekasan.ac.id\%2Findex.php\%2Fokara\%2Farticle\%2Fdownload\%2 F458\%2F444\&usg=AOvVaw0xki9HDKuAyGy-LV-TaLvf on February 18, 2020.

[18] Seker, M., \& Dincer, A. (2014). An insight to students' perceptions on teacher feedback in second language writing classes. English Language $\quad$ Teaching, $7(2), \quad 73-83 . \quad$ Retrieved from https://www.researchgate.net/publication/272688324_An_Insight_to_Students\%27_Perceptions_on_Teacher_Feedback_in_Sec ond_Language_Writing_Classes on February 18, 2020.

[19] Sidorova, V. (2016). Corrective feedback in English language learners' writing. Retrieved from https://etd.ohiolink.edu/pg_10?0::NO:10:P10_ACCESSION_NUM:akron1478601224073001 on July 29, 2020.

[20] Smart, J. K. (2003). Real coaching and feedback: How to help people improve their performance. Glasgow: Pearson Education.

[21] Suarez, J. C. N. N., Cerezo, G. V. R., Rosario, P., \& Valle, A. (2015). Teachers' feedback on homework, homework-related behaviors, and academic achievement. The Journal of Educational Research, 108, 204-216. Retrieved from http://web.a.ebscohost.com/ehost/pdfviewer/pdfviewer?vid=4\&sid=9823cb5c-bd1f-43e9-a3abe1f87bbc2c47\%40sessionmgr4006 on May 24, 2020.

[22] Taggart, A. R., \& Laughlin, M. (2017). Affect matters: When writing feedback leads to negative feeling. International Journal for the Scholarship of Teaching and Learning, 11(2),1-11. Retrieved from https://files.eric.ed.gov/fulltext/EJ1150449.pdf on October 20, 2020.

[23] Tomczyk, E. (2013). Perceptions of oral errors and their corrective feedback: Teachers vs. students. Journal of Language Teaching and Research, 4(5), 924-931. $\quad$ Retrieved from http://web.a.ebscohost.com/ehost/pdfviewer/pdfviewer?vid=25\&sid=9823cb5c-bd1f-43e9-a3abe1f87bbc2c47\%40sessionmgr4006 on May 24, 2020.

[24] Tsao, J. J.; Tseng, W. T.; \& Wang, C. (2018). The effects of writing anxiety and motivation on EFL college students' selfevaluative judgments of corrective feedback. Psychological Reports, 120(2), 219-241. Retrieved from http://web.a.ebscohost.com/ehost/pdfviewer/pdfviewer?vid=9\&sid=19335186-1d85-463b-9ba9709a4a148253\%40sessionmgr4008 on May 24, 2020.

[25] Wiggins, G. (2012). Seven keys to effective feedback. Feedback for Learning, 70(1), 10-16. Retrieved from http://www.ascd.org/publications/educational-leadership/sept12/vol70/num01/Seven-Keys-to-Effective-Feedback.aspx on April 22, 2020.

[26] Wihastyanang, W. D.; Kusumaningrum, S. R.; Latief, M. A.; \& Cahyono, B. D. (2020). Impacts of providing online teacher and peer feedback on students' writing performance. Turkish Online Journal of Distance Education-TOJDE, 21(2), 178-190. Retrieved from http://web.a.ebscohost.com/ehost/pdfviewer/pdfviewer?vid=16\&sid=19335186-1d85-463b-9ba9709a4a148253\%40sessionmgr4008 on August 9, 2020.

[27] Zaman, M., \& Asad, A. K. (2012). Feedback in EFL writing at the tertiary level: Teachers' and learners' perceptions. ASA University Review, 6(1), 139-157. Retrieved from http://web.a.ebscohost.com/ehost/pdfviewer/pdfviewer?vid=15\&sid=9823cb5c-bd1f-43e9-a3abe1f87bbc2c47\%40sessionmgr4006 on April 19, 2020.

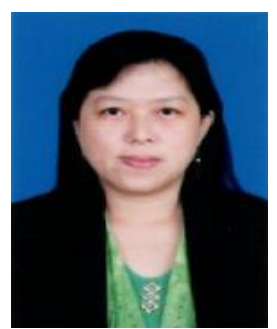

Listyani is an Associate Professor at the English Language Education Program (PBI), Faculty of Language and Arts (FBS), Universitas Kristen Satya Wacana (UKSW) Salatiga, Indonesia. She has been teaching there since March 1999. In August 2017, she got her Doctorate degree from State University of Semarang (UNNES) Indonesia, majoring in English Language Education. 